\title{
A note on naked oats as a substitute for wheat and barley for young pigs
}

\author{
A. Maślanek ${ }^{1}$, M. Flis ${ }^{1}$ and J. Falkowski ${ }^{2}$ \\ University of Warmia and Mazury \\ Oczapowskiego 5, 10-718 Olsztyn, Poland \\ 'Institute of Animal Nutrition and Feed Management \\ 'Department of Pig Breeding
}

\begin{abstract}
In a 28-day experiment on 18 gilts and 18 barrows of Polish Landrace x Duroc (18-42 kg body weight) the nutritional value of naked oats $\mathrm{cv}$. Akt was determined. Three diets (BW, $\mathrm{BO}$, and $\mathrm{O}$ ) containing 0,35 and $73.8 \%$ of oats, which formed 0,50 and $100 \%$ of the dietary cereals, were used. The BW control diet contained barley and wheat; the $\mathrm{BO}$ diet, only wheat; in the $\mathrm{O}$ diet, both wheat and barley were replaced by oats. The $\mathrm{BW}, \mathrm{BO}$ and $\mathrm{O}$ diets were supplemented with $2.5,1.6$, and $0 \%$ of soyabean oil, respectively. The daily feed intake (DFI), average daily gains (ADG), and feed conversion ratio $(\mathrm{FC})$ tended to be greater in the $\mathrm{BO}$ group fed the diet containing $35 \%$ oats than in groups BW and $\mathrm{O}$, respectively ( $907 \mathrm{vs} 822$ and $803 \mathrm{~g}$ and $1.85 \mathrm{vs} 2.00$ and $2.01 \mathrm{~kg} / \mathrm{kg} ; \mathrm{P}>0.05$ ). The results suggest that naked oats in an amount of $35 \%$ ( $50 \%$ of the diet cereals) can provide a good source of nutrients for young pigs.
\end{abstract}

Key words: naked oats, growth performance, pigs

\section{INTRODUCTION}

The naked oats grown in Poland contain 14.4-15.7\% crude protein of high biological value, $1.8-2.3 \%$ crude fibre and $7.6-8.0 \%$ ether extract in dry matter (Kosieradzka and Fabijańska, 1995; Maciejewicz-Ryś and Sokół, 1999). Earlier research showed that naked oat could be a successful alternative to maize in diets for pigs (Friend et al., 1988; Brand and van der Merwe, 1996).

Akt is the first Polish cultivar of naked oats (registered in 1997), and the area of its cultivation is constantly expanding. The aim of our experiment was to assess the nutritional value of this cultivar of naked oats as a replacement for wheat and barley in the feeding of young pigs. 


\section{MATERIAL AND METHODS}

The experiment was performed on 36 young pigs, 18 gilts and 18 barrows about $18.0 \mathrm{~kg}$ body weight, aged 8 weeks, crosses of Polish Landrace gilts and Duroc boars. The pigs, 12 in each group, were kept in pairs (one gilt and one barrow) in flat-deck cages fitted with self-feeders and automatic water nipples.

The pigs were fed on diets with naked oat $\mathrm{cv}$. Akt, supplying 0,50 and $100 \%$ of the cereal in diets $\mathrm{BW}, \mathrm{BO}$ and $\mathrm{O}$, respectively (Table 1 ). The soyabean control diet $\mathrm{BW}$ was composed of wheat and barley; oat $(35 \%)$ replaced wheat in diet BO; in diet $\mathrm{O}$ wheat and barley were substituted with oat $(73.81 \%)$. The cereal was ground to medium particles on a roller mill. The diets were balanced according to the Nutrient Requirements of Pigs (1993) and contained 1.09\% lysine and $0.32 \%$ methionine. The experiment lasted for 28 days, daily feed intake, average daily gains, and feed conversion ratio were determined.

One-way analysis of variance and the Duncan multiple range test were used to analyze the results of the experiment.

TABLE 1

Diets formulation and chemical conposition, $\%$

\begin{tabular}{lccc}
\hline & & Dicts & \\
\cline { 2 - 4 } Ingredicnts & BW & BO & O \\
\hline Barley & 36.3 & 33.71 & 0.0 \\
Wheat & 30.0 & 0.0 & 0.0 \\
Naked oat & 0.0 & 35.0 & 73.81 \\
Soyabean meal & 27.0 & 25.5 & 22.0 \\
Soyabcan oil & 2.5 & 1.6 & 0.0 \\
Limestone & 1.0 & 1.0 & 1.0 \\
Dicalcium phosplate & 1.6 & 1.6 & 1.6 \\
Salt & 0.3 & 0.3 & 0.3 \\
Lutamix PP-grower' & 0.5 & 0.5 & 0.5 \\
Lysine HCl (78\%) & 0.23 & 0.23 & 0.23 \\
Methionine (99\%) & 0.07 & 0.06 & 0.06 \\
Agricid & 0.5 & 0.5 & 0.5 \\
Analysed composition & & & 18.22 \\
crude protein & 18.36 & 18.96 & 5.71 \\
cther cxtract & 4.07 & 5.05 & 3.10 \\
crude fibre & 4.27 & 4.04 & 17.56 \\
gross energy, MJ/kg & 16.52 & 17.01 & \\
\hline
\end{tabular}

supplying per $\mathrm{kg}$ of diet: vit. A $13500 \mathrm{IU}$, vit. . $\mathrm{D}_{3} 2000 \mathrm{IU}$, vit $\mathrm{E} 40 \mathrm{mg}$, vit $\mathrm{K} 40 \mathrm{mg}$, vit $\mathrm{B}_{12} 2.5 \mathrm{mg}$, thiamine $4.0 \mathrm{mg}$, riboflavin $4.0 \mathrm{mg}$, pyridoxine $4.0 \mathrm{mg}$, calcium panthotenate $25.0 \mathrm{mg}$, niacin $25 \mathrm{mg}$, folic acid $1 \mathrm{mg}$, choline $350 \mathrm{mg}, \mathrm{Mg} 50 \mathrm{mg}$, Mn $60 \mathrm{mg}, \mathrm{J} 05 \mathrm{mg}, \mathrm{Zn} 150 \mathrm{mg}$, Fe $100 \mathrm{mg}, \mathrm{Cu}$ $160 \mathrm{mg}$, Co $0.3 \mathrm{mg}$, Se $0.2 \mathrm{Se}$

2 preparation with lactic acid 


\section{RESULTS}

Naked oat contained $11.4 \%$ protein, $2.8 \%$ crude fibre, and $7.2 \%$ ether extract. There were no significant differences in the daily feed intake between the diets, although the pigs tended to eat less of the diet with the maximum amount of oat $(1649,1676$ and $1609 \mathrm{~g}$ of the BW, BO and O diets, respectively) (Table 2). The average daily gains of pigs were high. The use of $35 \%$ naked oat as a substitute for wheat in the diet caused a non-significant increase in the growth rate of pigs (from 822 to $907 \mathrm{~g}$ daily). Oat used in an amount of $73.8 \%$ as the only cereal in diet $\mathrm{O}$ was as effective in terms of daily gains as a combination of barley and wheat supplemented with plant oil in the BW control diet. The pigs that received the barley-oat $(\mathrm{BO})$ diet were slightly better at feed efficiency compared with the pigs fed on the barley and wheat or oat diets (1.85 vs 2.00 and $2.01 \mathrm{~kg} / \mathrm{kg} ; \mathrm{P}>0.05)$.

TABLE 2 Average performance of pigs $(18-42 \mathrm{~kg}$ ) fed during 28 days on diets containing $\mathrm{O}(\mathrm{BW}), 35(\mathrm{BO})$ and about $74(\mathrm{O}) \%$ of naked oat

\begin{tabular}{lcccr}
\hline & \multicolumn{4}{c}{ Group } \\
\cline { 2 - 5 } Itcm & $\mathrm{BW}$ & $\mathrm{BO}$ & $\mathrm{O}$ & $\mathrm{SE}^{\prime}$ \\
\hline No. of animals & 12 & 12 & 12 & \\
Initial weight, $\mathrm{kg}$ & 17.7 & 18.0 & 17.9 & 0.62 \\
Final weight, $\mathrm{kg}$ & 40.7 & 43.4 & 40.4 & 1.09 \\
Daily feed intake, $\mathrm{g}$ & 1649 & 1676 & 1609 & 54.70 \\
Average daily gain, $\mathrm{g}$ & 822 & 907 & 803 & 20.80 \\
Feed conversion ratio, $\mathrm{kg} / \mathrm{kg}$ & 2.00 & 1.85 & 20.01 & 0.04 \\
\hline
\end{tabular}

${ }^{1}$ standard crror

\section{DISCUSSION}

The results show that naked oat in an amount of $35 \%$ (50\% of the dietary cereal) was willingly consumed and provided a good source of nutrients for young pigs, with its nutritional value being superior when applied in a combination with barley to that of a barley and wheat diet. Growth performance of pigs did not improve when the contribution of oat was increased to $73.8 \%$ of the diet. However, the daily feed intake slightly decreased. In the experiments on younger pigs, the intake of diets containing 71.5 or $73.8 \%$ of naked oat decreased significantly (Brand and van der Merwe, 1996; Falkowski et al., 2000). It was found that in diets for pigs growing from 8.7 to $21 \mathrm{~kg}$ of body weight, the amount of naked oat should not exceed $47.9 \%$ (Brand and van der Merwe, 1996). 
In our experiment, the use of naked oat saved high-protein feed, such as soyabean meal, and fat in the nutrition of young pigs.

\section{CONCLUSIONS}

Naked oat is a valuable cereal dietary component for young pigs and can replace up to $74 \%$ of wheat and/or barley and save feed protein and fat.

\section{REFERENCES}

Brand T.S., van der Merwe J.P., 1996. Naked oats (Avena nuda) as a substitute for maize in diets for weanling and grower-finisher pigs. Anim. Feed Sci. Tech. 57, 139-147

Falkowski J., Flis M., Kozera W., Bugnacka D., Białkowski J., Pająk J., 2000. Palatability trial determination of a diet supplement with naked oats in weaned piglet feeding. Natur. Sci. 7 , $169-178$

Friend D.W., Fortin A., Poste L.M., Butler G., Kramer J.K.G., Burrows V.D., 1988. Feeding and metabolism trials, and assesment of carcass and meat quality for growing-finishing pigs fed naked oats. Can. J. Anim. Sci. 68, 511-521

Kosieradzka l., Fabijańska M., 1995. Biological value of protein selected varieties of oats grain (in Polish). In: Proceedings of XXV Conference on Animal Nutrition, Poznań (Poland), pp. 35-37

Maciejewicz-Ryś J., Sokól J., 1999. Nutritive value of protein of covered oat (Avena sativa L.) and naked oat (A.sativa varnuda) grain (in Polish). Food 1 (18), Suppl., 273-278

Nutrient Requirement of Pigs. Nutritive Value of Feeds (in Polish), 1993. The Kielanowski Institute of Animal Physiology and Nutrition (Editor). Jabłonna (Poland)

\section{STRESZCZENIE}

\section{Owies nagi jako zamiennik pszenicy i jęczmienia w dawkach dla mlodych świń}

W 28-dniowym doświadczeniu na 18 loszkach i 18 wieprzkach rasy pbz x Duroc (18-42 kg) badano wartość pokarmową nagiego owsa odmiany Akt. Stosowano trzy mieszanki (BW, BO i O) zawierające odpowiednio 0,35 i ok. $74 \%$ owsa, który stanowił 0,50 i $100 \%$ zboża dicty. Kontrolna mieszanka BW zawicrała jęczmień i pszenicę, w mieszance BO owsem zastapiono pszenicę, a w mieszance $\mathrm{O}$ owsem zastapiono pszenicę i jęczmień. Mieszanki BW, BO i O uzupełniono olejem sojowym w ilości odpowiednio 2,$5 ; 1,6$ i $0 \%$. Określono pobranie paszy (DFI), dzienne przyrosty (ADG) i wykorzystanie paszy (FC). Stwierdzono tendencję zwiększenia ADG i FC w grupie BO żywionej mieszanką z udziałem 35\% owsa, w porównaniu z grupą BW i O (907 vs 822 i 803 g i 1,85 vs 2.00 i $2,01 \mathrm{~kg} / \mathrm{kg} ; \mathrm{P}>0,05$ ).

Wyniki wskazują, że nagi owies w ilości $35 \%$ ( $50 \%$ zboża w mieszance) może być bardzo dobrym źródłem składników pokarmowych dla młodych świn. 